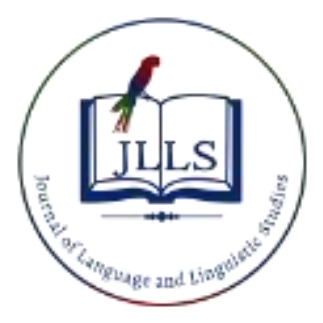

Available online at www.jlls.org

JOURNAL OF LANGUAGE AND LINGUISTIC STUDIES

ISSN: 1305-578X

Journal of Language and Linguistic Studies, 16(2), 757-774; 2020

\title{
The role of phonological knowledge and rapid naming in the development of
}

$$
\text { spelling and reading in Turkish }
$$

\section{APA Citation:}

\author{
Yeliz Yilmaz Korkmaz $^{\text {a (D), Nalan Babür }}{ }^{\text {(iD), Belma Haznedar }}{ }^{\text {c1 }}$ (D) \\ ${ }^{a}$ Ylldiz Technical University, Istanbul, Turkey \\ ${ }^{b}$ Boğaziçi University, Istanbul, Turkey \\ ${ }^{b}$ Boğaziçi University, Istanbul, Turkey
}

APA Citation:

Yllmaz Korkmaz, Y., Babür, N., \& Haznedar, B. (2020). The role of phonological knowledge and rapid naming in the development of spelling and reading in Turkish. Journal of Language and Linguistic Studies, 16(2), 757-774.

Submission Date: 24/12/2019

Acceptance Date: 30/03/2020

\begin{abstract}
This study explores reading and spelling development of Turkish-speaking children in Grade 1 and 2. We examined predictors of word spelling and reading skills as well as the developmental relationship between spelling and reading abilities. Our major focus was on the role of phonological encoding skills and rapid automatized naming (RAN) in reading and spelling. Data were gathered from 71 students and analyzed quantitatively. The results showed that phonological encoding was a significant predictor of spelling skills while RAN was a strong predictor of reading skills in Turkish. Besides, phonological encoding significantly contributed to the reading skills of the second graders while it did not account for significant amounts of variance in word reading ability of the first graders.
\end{abstract}

(C) 2020 JLLS and the Authors - Published by JLLS.

Keywords: reading; spelling; phonological encoding; rapid automatized naming; Turkish

\section{Introduction}

Reading and spelling are two essential skills that are important to the development of literacy (Otto, 2008). Given that literacy is a fundamental skill in modern life to have access to knowledge and share information across generations, it is crucially important to understand the linguistic and cognitive principles and predictors of literacy development (Caravolas \& Samara, 2015). Among others, phonological awareness and rapid automatized naming (RAN) are two of the variables that have long been noted to have critical roles in the development of spelling and reading (Gentry, 1982). Phonological awareness, for instance, has been found to be a significant predictor of learning to read and spell in different languages such as English (Bradley \& Bryant 1983; Caravolas, Hulme, \& Snowling, 2001; Torgesen, Wagner, Rashotte, Burgess, \& Hecht, 1997), Czech (Caravolas, Volin, \& Hulme, 2005), German (Goswami \& Bryant, 1990), Greek (Nikolopoulos, Goulandris, Hulme, \& Snowling, 2006) and

\footnotetext{
${ }^{1}$ Corresponding author. Tel.: +90-212-359-6903

E-mail address: haznedab@boun.edu.tr
} 
Turkish (Öney \& Durgunoglu, 1997) while RAN is found to be a strong predictor of reading (Bowers \& Wolf, 1993; Kirby, Parrila, \& Pfeiffer, 2003; Norton \& Wolf, 2012; Wolf \& Bowers, 1999).

\subsection{Literature review}

\subsubsection{The relationship between reading and spelling skills}

Reading and spelling skills are two abilities that constitute literacy and there are different views about the relationship between these two skills. Research in different languages has shown that despite many similarities, reading and spelling development differ largely across languages (Joshi \& Aaron, 2006). Many researchers proposed that at the beginning of literacy acquisition process, reading and spelling are quite different abilities, which is called as discrepancy hypothesis (Bryant \& Bradley, 1980; Frith, 1980; Goswami \& Bryant, 1990). According to the discrepancy hypothesis, at the beginning of the acquisition process, children are likely to read visually (holistically) while they tend to spell segmentally (phonologically). At later stages, the two skills are claimed to become linked. The hypothesis claims that spellings of the beginners show phonemically segmented word representations. However, unlike spelling, their reading mainly depends on overall shapes of words. In other words, while learners can use phonological awareness effectively for spelling, they are not able to use it for reading (FletcherFlinn, Shankweiler, \& Frost, 2004).

With regard to the discrepancy hypothesis, the model proposed by Frith (1985) provides a theoretical framework with an interaction between reading and spelling skills. Frith (1985) identifies reading development with three phases which are identified with three skills. The first stage is called logographic, and the strategy used in this stage is the instant recognition of familiar words. In other words, children recognize the word as a whole and then pronounce it with the help of important visual cues, like salient graphic features. Despite being able to recognize familiar words, they are almost unable to write more than a few words from memory since full cues are required for spelling (Eme \& Golder, 2005).

The second stage, the alphabetic stage, is characterized by the strategy to know and use individual phonemes and graphemes and their correspondences. It involves decoding grapheme by grapheme. Unlike logographic stage, letter order and phonological components play an important role in this stage (Frith, 1985). Starting to spell by building up correspondences between sounds (phonemes) and letters (graphemes) shows the entry to the alphabetic stage. Children then apply this skill-awareness of the relationships between sounds and letters- to reading and gradually become competent to use phonological decoding for new and nonsense words (Eme \& Golder, 2005).

In the third stage, the orthographic phase, children can instantly analyze words into orthographic units without phonological conversion. By the recombination of these units, children can create an unlimited number of words. As a result, reading and spelling become independent of phonological strategies (Frith, 1985). Based on this three-phase literacy development model, Frith (1985) came up with a new one: Six-Step Model.

In the model (Table 1), each stage is divided into two steps for reading and spelling skills. In each step, reading or spelling may be the leading strategy used in that particular step. That is, when logographic strategy reaches an advanced level, it becomes ready to be used for spelling. When the alphabetic (phonological) strategy is first adopted for spelling, the logographic strategy is still in use for reading. As soon as the alphabetic (phonological) strategy reaches an advanced level, it will be adopted for reading. That is, the alphabetic strategy paves the way for the use of this strategy in reading (Ellis, 1994). 
Table 1. Frith's six-step model of reading and spelling development (Frith, 1985)

\begin{tabular}{lll}
\hline Step & Reading & Spelling \\
\hline $1 \mathrm{a}$ & Logographic & (Symbolic) \\
$\mathrm{b}$ & Logographic & Logographic \\
$2 \mathrm{a}$ & Logographic & Alphabetic \\
$2 \mathrm{~b}$ & Alphabetic & Alphabetic \\
$3 \mathrm{a}$ & Orthographic & Alphabetic \\
$3 \mathrm{~b}$ & Orthographic & Orthographic \\
\hline
\end{tabular}

Source: Frith (1985, p. 311)

According to the model, as spelling uses alphabetic strategy longer than reading, the reading skill moves from phonological stage to orthographic stage earlier than spelling skill. This makes spelling skill phonologically oriented for a longer time, compared to reading. In the last stage, while reading skills mainly use orthographic strategy, alphabetic (phonological) strategies are utilized by spelling skills for a longer time (Frith, 1985). It is assumed that in the last stage, extensive reading practice using alphabetic strategy strengthens the analysis of letter series in words. As a result, this helps the reader develop orthographic representations letter by letter. Then, these representations are transferred to the spelling skill. Thus, reading paves the way for orthographic spelling (Ellis, 1994).

As can be seen, Frith's stage model provides a broad framework for describing the link between reading and spelling skills in an opaque language, English. However, it is not known for certain whether this model can explain the development of literacy skills in transparent languages (e.g., such as Finnish, Italian, Turkish, etc.) (Lehtonen, 2006). Therefore, conducting literacy research in different languages, especially in transparent ones is likely to be significant as it will give the opportunity to compare and contrast the literacy development processes in alphabetic languages.

\subsubsection{The role of phonological awareness in reading and spelling development}

Phonological awareness can be defined as one's ability to notice, think about, or manipulate the individual sounds or phonemes in words (Torgesen et al.,1997). In a number of studies conducted in many alphabetic writing systems, phonological awareness is found to be a core component of literacy development in consistent (Caravolas, Volin \& Hulme, 2005; Nikolopoulos et al., 2006; Öney \& Durgunoglu, 1997) and inconsistent orthographies (Bradley \& Bryant 1983; Gillon, 2007; Wagner et al., 1997).

Furthermore, the relationship between phonological awareness and the reading ability has been extensively examined in English and phonological awareness is turned out to be one of the most powerful predictors of reading development in English (e.g., Kirby, Parrila, \& Pfeiffer, 2003; Muter, Hulme, Snowling, \& Stevenson, 2004; Torgesen et al., 1997). However, there has been contradictory research evidence from consistent orthographies. While some studies conducted in orthographically consistent languages have revealed that phonological awareness may not be an important predictor of reading (e.g., Aarnoutse, van Leeuwe, \& Verhoeven, 2005; Babayiğit \& Stainthorp, 2007), other studies indicated that phonological awareness may be important, but only during the first grades (e.g., de Jong \& van der Leij, 2002; Furnes \& Samuelsson, 2010; Wimmer, Mayringer, \& Landerl, 2000).

Despite the mixed findings across languages, it appears that the relationship between phonological awareness and reading is more distinct in opaque orthographies (e.g., English, French) than many transparent ones (e.g., Finnish, Turkish). The reason for this may be "the time" needed to establish reliable grapheme-phoneme recording procedures in different languages (Goswami, Ziegler, \& Richardson, 2006; Seymour, Aro, \& Erskine, 2003). During reading development in transparent orthographies, it is likely to be an almost effortless challenge as one letter or a letter cluster is normally 
pronounced in the same way. However, in less transparent or opaque orthographies such as English, letters can have multiple pronunciations and this fact places heavier demands on understanding and applying phonological awareness skills (Furnes \& Samuelsson, 2011).

Unlike reading, spelling is a more sensitive index of phonological awareness skills than reading (Perfetti, 1997). Much evidence is presented in support of the relationship between spelling and phonological awareness across languages (Aidinis \& Nunes, 2001; Caravolas et al., 2005; Plaza \& Cohen, 2003). On the other hand, several studies conducted in consistent writing systems such as Dutch, German, and Turkish have concluded that phonological awareness skills play a more central role in children's early spelling development than reading development (Babayiğit \& Stainthorp, 2007; Landerl \& Wimmer, 2008; Wimmer \& Mayringer, 2002).

In line with these studies on transparent languages, Babayiğit and Stainthorp (2011) conducted a longitudinal study to examine the central components of reading and spelling skills in Turkish with the testing battery of tasks including phonological awareness and RAN. One hundred and three Turkish Cypriot children from 2nd and 4th grades were followed for a year into 3rd and 5th grades respectively to monitor the roles of phonological awareness and RAN in reading and spelling among older age groups. They found that phonological awareness was the strongest predictor of spelling, even among older children, whereas RAN was a powerful predictor of reading skill.

In another study by Sönmez (2015), 77 Turkish- speaking children in Grade 3 and 4 were assessed in order to find out the role of phonological awareness skills and RAN in predicting reading and spelling achievement. The results showed that phonological awareness was a significant predictor of spelling skill in Turkish while RAN was a strong predictor of reading skill. However, independent of phonological awareness skills, RAN was also found to make a significant contribution to spelling achievement at both grade levels. That is, as the grade level increased, the role of phonological skills tended to decrease while RAN started to play a more significant role both in reading and spelling performance.

In short, previous research showed that phonological awareness is one of the most powerful predictors of reading development mostly in opaque languages, namely in English. In contrast, in transparent orthographies, especially in Turkish, the relationship between phonological awareness and reading is found to be less informative. However, regarding spelling, in transparent orthographies, phonological awareness skills are found to have a significant role in spelling development.

\subsubsection{The role of rapid automatized naming $(R A N)$ in reading and spelling development}

Rapid automatized naming (RAN) is defined as the ability to verbalize the accurate name of visually presented stimuli such as digits, letters, colors, and objects, as quickly and correctly as possible (Denckla \& Rudel, 1976a, 1976b). Starting with the research by Denckla and Rudel (1974, 1976a, 1976b), a considerable amount of cross-linguistic research has suggested that RAN is strongly associated with reading ability (e.g., Babayiğit \& Stainthorp, 2010; Badian, 1993; Bowers \& Swanson, 1991; Cornwall, 1992; Norton \& Wolf, 2012; Wimmer \& Mayringer, 2002).

In contrast to abundant amount of research on the relationship between reading and RAN, studies examining the relationship between RAN and spelling were limited. Thus, the relationship between RAN and spelling skills has started to attract attention in the literature in a number of studies. It was considered that there should be a relationship between RAN and spelling across languages since spelling depends upon the nature of the orthographic representations. These representations, defined as memories of words' spellings (Georgiou, Torppa, Manolitsis, Lyytinen, \& Parrila, 2012, p.325), are indexed by RAN (Bowers \& Wolf, 1993).

A few studies have investigated the relationship between RAN and spelling in opaque languages, English in particular, and found that RAN predicts spelling (Furnes \& Samuelsson, 2011; Georgiou et. 
al., 2012; Savage, Pillay, \& Melidona, 2008; Stainthorp, Powell, \& Stuart, 2013; Verhagen, Aarnoutse, \& Van Leeuwe, 2010). In contrast, some recent findings from studies on languages with regular orthographies showed that RAN was not predictive of spelling (Babayiğit \& Stainthorp, 2010; Landerl \& Wimmer, 2008; Nikolopoulos et. al., 2006; Wimmer \& Mayringer, 2002). In a longitudinal study by Landerl \& Wimmer (2008), 115 students from Grade 1 to 8 were investigated to find out the development of word reading fluency and spelling in German. The results showed that RAN was the strongest predictor for reading fluency while phonological awareness was found to predict spelling in German. In another study by Babayiğit \& Stainthorp (2010), 57 Turkish speaking children were followed from Grade 1 to 2 to investigate the role of RAN skills in reading and spelling development in the transparent orthography of Turkish. They found that RAN was a powerful and consistent predictor of reading skill, but not of spelling.

To sum up, these studies showed that RAN was a strong predictor of reading ability regardless of the transparency of the language. However, in transparent languages such as Turkish (Babayiğit \& Stainthorp, 2010) and German (Wimmer, Landerl, \& Frith, 1999), RAN did not have a predictive role on spelling although it was strongly associated with spelling in opaque languages like English.

\subsection{Research questions}

The primary purpose of this study is to examine the role of phonological awareness and RAN in Turkish spelling and reading development across first and second grades of elementary school. Despite detailed investigation of these factors and their roles in reading in the literature, little research has focused on phonological awareness and RAN in spelling performances of Turkish speaking children (e.g., Babayiğit \& Stainthorp, 2010; Sönmez, 2015). Thus, this study aims to gain more insight into Turkish spelling skills by examining the roles of phonological awareness and RAN in spelling performances of students in the early years of schooling.

The study has attempted to answer the following research questions:

1. What are the intercorrelations among phonological encoding, RAN, word reading and word spelling? Does the relationship differ in the $1^{\text {st }}$ and $2^{\text {nd }}$ grade?

2. Do phonological encoding skills and RAN contribute significantly to spelling ability of $1^{\text {st }}$ and $2^{\text {nd }}$ graders? Does this relationship differ in the $1^{\text {st }}$ and $2^{\text {nd }}$ grade?

3. Do phonological encoding skills and RAN contribute significantly to reading ability of $1^{\text {st }}$ and $2^{\text {nd }}$ graders? Does this relationship differ in the $1^{\text {st }}$ and $2^{\text {nd }}$ grade?

\section{Method}

The present study aims to investigate the role of phonological awareness and RAN as predictors of reading and spelling skills of monolingual Turkish-speaking children during the first 2 years of schooling. We examined a sample of Turkish first and second graders with a battery of tests to measure phonological awareness skills and RAN in order to investigate their contribution to reading and spelling abilities. In the current study, in accordance with Savage et al. (2008), phonological awareness was measured in the form of phonological encoding skills by using a nonword spelling task. As the nonwords are not directly retrieved from the lexicon, grapheme-phoneme correspondence rules are needed for their processing in the spelling task. Thus, these kinds of tasks are generally considered as a direct measure of the ability to apply encoding skills (Savage et al., 2008). 
We hypothesized that phonological awareness, measured in the form of phonological encoding skills, would have strong correlations with the spelling ability while RAN would strongly correlate with reading regardless of the grade level. Also, RAN was expected to predict reading ability across grades and phonological awareness was expected to predict spelling development in Grade 1 and 2.

\subsection{Sample / Participants}

The participants of the study were a total of 71 first and second grade students in a state school located in a low-income area of northern Istanbul, Turkey. They were tested midway through the second term of the school year. None of the students repeated their first year and none of them were reported to have any known psychological, intellectual or emotional problems. Table 2 lists demographic information about the participants.

Table 2. Mean age (standard deviation), gender, and total sample size at Grade 1-2

\begin{tabular}{ccc}
\hline & Grade 1 & Grade2 \\
\hline Age in months & $81(6)$ & $94(7)$ \\
Girls (\%) & $20(28)$ & $18(25)$ \\
Boys (\%) & $16(23)$ & $17(24)$ \\
Total sample size & 36 & 35 \\
\hline
\end{tabular}

\subsection{Instrument( $s)$}

In the present study, four different tests were used in order to assess the reading and spelling abilities of Turkish speaking children.

\subsubsection{Word level reading}

This subtest was used as a measure of reading decoding ability of the participants. In the test, participants were asked to identify seven letters and to read 64 isolated words of increasing difficulty. The test was discontinued after six consecutive errors. The Cronbach's alpha coefficient was .96 .

\subsubsection{World level spelling}

This test was developed by the first researcher for this study to measure the spelling ability of the participants. It includes 35 isolated words of increasing difficulty which were chosen from a corpus of the words in Turkish books used for Turkish classes in first and second grades. Based on the frequencies of the words in the books, 35 most frequent words were determined among each syllable group- from 1-syllable to 9-syllable. Both inflected and uninflected words were included in the test in order to display morphological richness of Turkish. In the test, the participants were given answer sheets and asked to write the isolated words they heard while the researcher was reading aloud the words twice after the presentation of two practice items. The overall internal reliability measure (Cronbach's alpha) of the test was found to be .90 .

\subsubsection{Phonological encoding}

This test was used to measure the knowledge on phonological patterns of word forms, especially the ability to write the sounds using phonological encoding skills. The test includes 39 items ( 7 phonemes and 32 nonwords). The participants were expected to write the items on an answer sheet while the researcher was dictating them twice. Before starting the test, participants got familiarized by practice 
items for both writing phonemes and nonwords. The test was discontinued after four consecutive errors. The internal reliability measure of the test was found to be .98 .

\subsubsection{RAN (Digits)}

HOTI (digits) (Bakır \& Babür, 2009, 2018) was used as a measure for rapid naming skills of the participants. In the digit naming test, the participant was asked to name a series of 50 items. The test items included the numbers $2,4,6,7$, and 9 , which are arranged randomly in a 10x5 matrix. The participant was required to read aloud the rows from left to right as fast and accurately as possible.

\subsection{Data collection procedures}

All tests were administered to the first and second graders between April and June during school days. Before implementing the tests, an official permission from the Ministry of National Education was obtained as well as the consent of the school administration, the teachers and the parents. All the participants were administered word reading, RAN (Digits), and phonological encoding tests individually in a quiet room in their school. The word spelling test was carried out through group administration in the classroom. It took nearly eight weeks to administer all the tests to all participants.

All tests were administered by the first researcher. Firstly, word spelling test was administered to the first graders and second graders. Then, the other tests were administered in the following order: word reading, rapid digit naming, and phonological encoding. All the participants were ensured to have a pen and an eraser before the administration of the tests.

\subsection{Data analysis}

The first and second grade students were given several tests including spelling, phonological encoding, reading and rapid naming to investigate the underlying components of the spelling and reading ability. To evaluate the quantitative data gathered from the participants, it was entered into 20.0 version of SPSS (Statistical Package for Social Sciences) to conduct statistical analyses. Before conducting the analyses, the distribution of the scores was examined and some outliers were removed. The normality tests were carried out to see whether the data have a normal distribution. The results of the normality tests, skewness and kurtosis values showed that the scores had a normal distribution.

In order to see the intercorrelations between phonological skills, RAN, word reading and word spelling scores, Pearson product-moment correlations were run. Lastly, two-step multiple regressions (hierarchical model) were run in order to examine the effects of phonological encoding and rapid naming on students' word spelling and word reading skills.

\section{Results}

In the current study, we examined the contributions of phonological awareness and rapid naming to reading and spelling abilities of Turkish- speaking children in Grade 1 and 2. It was hypothesized that phonological awareness would make unique contributions to spelling skill at each grade. In addition, RAN was predicted to contribute significantly to reading ability across grades. We examined our research questions using correlational and a series of hierarchical regressions analyses.

\subsection{Descriptive statistics}

Descriptive statistics (i.e., means, standard deviations, minimum and maximum scores) are presented in Table 3. All the tests, except the RAN test, were registered as total number correct, with higher scores 
indicating better performance. The RAN task was reported in terms of seconds, that is, shorter times indicated better performance.

Table 3. Descriptive statistics for Grade 1 and Grade 2

\begin{tabular}{ccccccc}
\hline & \multicolumn{3}{c}{ Grade 1} & & \multicolumn{2}{c}{ Grade 2} \\
$\begin{array}{c}\text { Tests } \\
\text { (Maximum Score) }\end{array}$ & Min. & Max. & Mean (SD) & Min. & Max. & Mean (SD) \\
\hline $\begin{array}{c}\text { Word Reading (76) } \\
\text { Word Spelling by Dictation } \\
(35)\end{array}$ & 26 & 53 & $38,66(7,33)$ & 40 & 71 & $56,74(8,76)$ \\
RAN & 2 & 35 & $21,94(7,73)$ & 8 & 35 & $25,31(7,68)$ \\
Phonological Encoding (49) & 26.12 & 66.29 & $40,76(9,43)$ & 21.63 & 52.34 & $31,79(7,11)$ \\
\hline
\end{tabular}

As can be seen in Table 3, the scores on all measures in Grade 1 and 2 showed good variability with no floor or ceiling effects. Descriptives show that the participants in Grade 2 had better scores on all measures than first graders. In the first grade, the participants spelled an average of 22 words and read an average of 38 words. However, the second graders spelled and read an average of 25 and 56, respectively.

\subsection{Relationships between reading and spelling measures}

Bivariate correlations were calculated among the measures for children of Grade 1 and 2 separately. As can be seen in Table 4, all correlations were statistically significant and ranged from low to high. Correlations of the word spelling task with the RAN task were non-significant in the first and second grade.

Table 4. Correlation Matrix for Interrelations among Measures for Grade 1 and Grade $2^{+}$

\begin{tabular}{ccccc}
\hline Variables & 1 & 2 & 3 & 4 \\
\hline 1. Word spelling & -- & $.482^{* *}$ & $.408^{*}$ & -.212 \\
& & & $-.418^{*}$ \\
2. Phonological encoding & $.805^{* *}$ & -- & $.453^{*}$ & $-.555^{* *}$ \\
3. Word reading & .316 & .174 & -- \\
4. RAN-digit & -.192 & -.095 & $-.454^{* *}$ & - \\
Note. $* \mathrm{p}<.05, * * \mathrm{p}<.01$ \\
+ First grade students located below diagonal, second grade students located above diagonal.
\end{tabular}

In the first grade, measures of word spelling and phonological encoding were highly correlated with one another $(\mathrm{r}=.80, \mathrm{p}<.01)$. Regarding reading scores of first graders, unlike spelling, there was a statistically significant negative correlation between word reading skills and rapid naming $(r=-.45, p<$ $.01)$.

In Grade 2, word spelling and word reading skills of the second graders significantly correlated with each other $(r=.40, \mathrm{p}<.05)$. Despite the strong correlation between phonological encoding skills and the spelling ability of the first graders, word spelling was moderately correlated with phonological encoding 
in Grade $2(\mathrm{r}=.48, \mathrm{p}<.01)$. Similar to first graders, rapid naming and reading ability significantly correlated $(\mathrm{r}=.55, \mathrm{p}<.01)$.

\subsection{Hierarchical regression analysis}

Hierarchical regression analyses were performed in order to find out the contribution of phonological encoding skills and RAN to spelling and reading abilities of first and second graders. Two different sets of hierarchical regression analyses were conducted for spelling and reading abilities at each grade. The first set of analyses examined the contributions of phonological encoding skills and RAN to spelling ability. For the entry sequence of the variables to the word spelling ability model, the correlations among the variables and theoretical rationale were taken into account. In the analyses for each grade, with regard to the previous studies, phonological encoding was entered in the first step since it was demonstrated as the most influential variable on spelling ability. Then, RAN was included as Step 2.

As can be seen in Table 5 and 6, phonological encoding skills uniquely explained a significant variance in spelling at each grade. In contrast, RAN did not explain any unique variance in spelling performance of the students in Grade 1 and Grade 2. When the results of the first and second grade were compared, it was seen that phonological encoding skills explained a unique $65 \%$ of variance in word spelling ability in Grade $1(\mathrm{~F}(1,32)=58.981, \mathrm{p}<.001)$, whereas the contribution of phonological encoding in Grade 2 was much smaller $(23,2 \%)(\mathrm{F}(1,29)=8.777, \mathrm{p}<.01)$.

Table 5. Hierarchical Regression Analysis for Word Spelling at Grade $1(\mathrm{~N}=34)$

\begin{tabular}{cccccc}
\hline Independent variable & $\mathrm{B}$ & $\mathrm{t}$ & $\mathrm{R}$ & $\mathrm{R}^{2}$ & $\Delta \mathrm{R}^{2}$ \\
\hline Step 1 & & & .805 & .648 & .637 \\
PE & .805 & $7,680^{* * * *}$ & & & \\
Step 2 & & & .813 & .662 & .640 \\
PE & .794 & $7,568^{* * *}$ & & \\
RAN & -.117 & $-1,111$ & &
\end{tabular}

Note. $\mathrm{PE}=$ Phonological Encoding, RAN = Rapid Automatized Naming. $\mathrm{B}=$ Standardized Beta, $\Delta \mathrm{R}^{2}=\mathrm{R}$ Squared Change. ${ }^{*} \mathrm{p}<.05$, $* * \mathrm{p}<.001$.

Table 6. Hierarchical Regression Analysis for Word Spelling at Grade $2(\mathrm{~N}=35)$

\begin{tabular}{cccccc}
\hline Independent variable & $\mathrm{B}$ & $\mathrm{t}$ & $\mathrm{R}$ & $\mathrm{R}^{2}$ & $\Delta \mathrm{R}^{2}$ \\
\hline Step 1 & .482 & $2,963^{* * *}$ & & .482 & .206 \\
PE & & & .484 & .234 & .179 \\
Step 2 & .500 & $2,747^{* *}$ & & \\
PE & -.044 & -.239 & &
\end{tabular}

Note. $\mathrm{PE}=$ Phonological Encoding, RAN = Rapid Automatized Naming. $\mathrm{B}=$ Standardized Beta, $\Delta \mathrm{R}^{2}=\mathrm{R}$ Squared Change. $* \mathrm{p}<.05$, $* * \mathrm{p}<.001$

The second set of analyses examined the contributions of phonological encoding skills and RAN to reading ability. In these analyses for each grade, rapid naming (RAN) was entered as one step since it was found to be the most influential variable on reading ability in the previous studies. Then, 
phonological encoding was included as Step 2. Table 7 and 8 show the results of hierarchical regression analysis for word reading skills across grade levels. The results show that rapid naming skills made a significant contribution to word reading ability at each grade. It was found that rapid naming skills accounted for $21 \%$ of the total variance $(\mathrm{F}(1,32)=8.320, \mathrm{p}<.01)$ at Grade 1 and $29 \%$ of the total variance $(\mathrm{F}(1,28)=11.332, \mathrm{p}<.01)$ at Grade 2 in reading achievement. Phonological encoding skills contributed to word reading at Grade 2, however, it did not make a contribution to word reading at Grade 1. When the results across grade levels were compared, it was seen that phonological encoding skills contributed word reading ability in Grade $2(8 \%)$ more than in Grade $1(1,4 \%)$. Moreover, there was an increase in the amount of variance RAN performance accounted for in word reading ability ( $21 \%$ at Grade $1,29 \%$ at Grade 2).

Table 7. Hierarchical Regression Analysis for Word Reading at Grade $1(\mathrm{~N}=34)$

\begin{tabular}{cccccc}
\hline Independent variable & $\mathrm{B}$ & $\mathrm{t}$ & $\mathrm{R}$ & $\mathrm{R}^{2}$ & $\Delta \mathrm{R}^{2}$ \\
\hline Step 1 & & & .454 & .206 & .182 \\
RAN & -.454 & $-2,884^{* *}$ & & & \\
Step 2 & & & .473 & .224 & .174 \\
RAN & -.442 & $-2,779^{* *}$ & & \\
PE & .132 & .832 & & &
\end{tabular}

Note. $\mathrm{PE}=$ Phonological Encoding, RAN = Rapid Automatized Naming. $\mathrm{B}=$ Standardized Beta, $\Delta \mathrm{R}^{2}=\mathrm{R}$ Squared Change. ${ }^{*} \mathrm{p}<.05$, $* * \mathrm{p}<.001$.

Table 8. Hierarchical Regression Analysis for Word Reading at Grade $2(\mathrm{~N}=34)$

\begin{tabular}{cccccc}
\hline Independent variable & $\mathrm{B}$ & $\mathrm{t}$ & $\mathrm{R}$ & $\mathrm{R}^{2}$ & $\Delta \mathrm{R}^{2}$ \\
\hline Step 1 & & & .537 & .288 & .263 \\
RAN & -.537 & $-3,366^{* *}$ & & & \\
Step 2 & & & .609 & .370 & .324 \\
RAN & -.432 & $-2,660^{*}$ & & & \\
PE & .305 & 1,877 & & &
\end{tabular}

Note. $\mathrm{PE}=$ Phonological Encoding, RAN $=$ Rapid Automatized Naming. $\mathrm{B}=$ Standardized Beta, $\Delta \mathrm{R}^{2}=\mathrm{R}$ Squared Change. ${ }^{*} \mathrm{p}<.05, * * \mathrm{p}<$ .001 .

\section{Discussion}

\subsection{The relationship between phonological encoding, $R A N$, word reading and word spelling}

This study was designed to investigate the role of phonological encoding skills and RAN in Turkish spelling and reading abilities of elementary school students in Grade 1 and 2. The results showed that there was a strong correlation between phonological encoding and word spelling while word reading and RAN were strongly correlated in each grade, which is in line with the findings of the previous research (Babayiğit \& Stainthorp, 2010, 2011; Landerl \& Wimmer, 2008; Sönmez, 2015; Wimmer \& Mayringer, 2002). Thus, this would suggest that first graders primarily rely on one-to-one phoneme-to- 
grapheme mapping and make use of the alphabetic strategy, phoneme-grapheme conversion strategies, when working on spelling tasks. On the other hand, during reading, they use automatization skills more than phoneme-grapheme conversion abilities when compared to spelling. That is, while reading, students do not make use of phoneme-grapheme conversion skills. Instead, they retrieve orthographic knowledge of words automatically. Moreover, during spelling, students make use of their phonological knowledge. This is consistent with Frith (1985) who argues that reading and spelling skills are closely related although they make use of different strategies at the beginning of acquisition processes. Children are likely to read visually (holistically) while they tend to spell phonologically. In accordance with this, the results showed that phonological awareness, assessed through phonological encoding skills, correlated more strongly with spelling than reading. However, RAN correlated more strongly with reading than spelling in Grade 1 and 2.

Taking differences at grade level into consideration, it was found that the strong correlation between phonological encoding skills and spelling was weakened as the grade level increased. However, RAN continued to have stronger correlations with reading when compared to Grade 1 . Besides, the results demonstrated that phonological encoding and reading are moderately correlated in Grade 2. Also, there is a moderate correlation between word reading and word spelling skills when compared to Grade 1, which is compatible with Frith (1985), as well. This means that first graders adopted phonological strategies for spelling, but in Grade 2, phonological strategy reached an advanced level so second graders started to adopt it also for word reading skills, which made reading and spelling associated with each other. However, as spelling skills use phonological strategies longer than reading, spelling stays phonologically oriented for a longer time compared to reading. Thus, in Grade 2, there is no correlation between RAN and word spelling. This is also in line with the discrepancy hypothesis (Bradley \& Bryant, 1980; Frith, 1980; Goswami \& Bryant, 1990), which proposes that reading and spelling abilities at first utilize different strategies and then they turn out to be closely related. In short, these findings indicate that the first graders use different strategies while reading and spelling: they spell phonologically but read holistically. Thus, the findings suggest that the discrepancy hypothesis and stage model by Frith (1985) are applicable to a transparent language, Turkish.

\subsection{The role of phonological encoding and RAN in word reading and word spelling}

The present study also aimed to investigate the contribution of phonological encoding skills and rapid naming in spelling and reading skills of the first and second graders in Turkish. The results showed that phonological encoding skills accounted for a significant amount of variance in word spelling. However, RAN did not make any significant contribution to spelling performance beyond phonological encoding skills, as it added little predictive power to word spelling ability. Thus, it can be suggested that in the beginning years of literacy education, word spelling in Turkish was predominantly based on students' phoneme-grapheme conversion abilities, probably because of the transparent nature of the Turkish language. This is consistent with Perfetti (1997) who proposes that phonological skills are considered to be a more sensitive indicator of spelling rather than reading (Perfetti, 1997).

It was also found that RAN made a significant contribution to reading skills in both grades beyond phonological encoding skills. To this end, the result replicated the findings of previous research, indicating that RAN is strongly associated with reading ability at both grade levels (Babayiğit \& Stainthorp, 2010; Badian, 1993; Bowers \& Swanson, 1991; Cornwall, 1992; Norton \& Wolf, 2012; Wimmer \& Mayringer, 2002).

Regarding the differences at grade levels, the results also showed that as the grade level increased, the influence of phonological awareness started to decrease, although it was still significantly important in predicting the spelling ability. However, there was no influence of RAN on spelling as the grade level 
increased. Thus, it can be concluded that phonological encoding skills had a dramatic contribution to word spelling in Turkish at Grade 1 and Grade 2 while RAN performance had almost no contribution. However, these findings contradict with the results of the study by Verhagen, Aarnoutse and Van Leeuwe (2010), who reported that phonological awareness and RAN were significant predictors of word spelling among Dutch speaking children in Grade 1 and 2. Spelling in Dutch in Grade 1 was predicted mainly by phonological awareness although there was significant but minor importance of rapid naming on spelling in Grade 1. However, spelling skill at the end of Grade 2 was predicted equally by phonological awareness and naming speed.

Regarding Frith's stage model (1985), on the other hand, the results of the study are compatible with the ones reported in Sönmez (2015) and Candan, Babür, Haznedar \& Erçetin (2020). These studies investigated the phonological encoding skills and RAN performance of third and fourth graders. The results showed that RAN significantly predicted the spelling ability of the students in the third and fourth grade. That is, third and fourth graders utilized automatization more during spelling. According to Frith's stage model (1985), automatization skills are adopted for spelling after they reached to an advanced level in reading. Thus, it can be concluded that automatization is adopted for spelling in third and fourth graders.

Regarding the differences at grade levels about reading skills, the influence of RAN tended to increase as the grade level increased. This result is likely to indicate that RAN becomes more influential in reading ability as automatization makes progress across grades. It was also seen that in Grade 2 phonological encoding started to make contribution to reading ability beyond RAN when compared to Grade 1 although it is not influential. This finding might indicate that after phonological encoding skills reach a mastery level, they are also started to be utilized by reading ability in addition to spelling as the grade levels increase. Thus, it can show that besides orthographic processes, second graders make use of phonological processes for reading, as well.

In short, the findings of the current study showed that, in Turkish literacy development, phonological encoding has predictive power on spelling performance while RAN is an index of reading skills. As the grade level increases, phonological encoding continues to be the stronger predictor of spelling, and RAN significantly predicts reading skills. However, with the progress in phonological strategies, phonological encoding makes small contributions to reading skills at higher grades.

\section{Conclusions}

The findings of the current study demonstrated that phonological awareness, which is measured in the form of phonological encoding skills, were found to be the predictor of spelling ability whereas RAN predicted reading performance significantly in Turkish across first and second grades of elementary school. This situation indicated that the students at Grade 1 and 2 were at different developmental stages regarding their spelling and reading skills, which is compatible with Frith's stage model (1985). In spelling, they were at the alphabetic stage, as indexed by their phonological encoding skills, on the other hand, in reading, they were at the orthographic stage, as indexed by their performance in rapid naming.

In Grade 1 and 2, the significant correlation between phonological encoding skills and the spelling ability indicated that spelling at Grade 1 and 2 was phonologically oriented. However, RAN was found to have no significant contribution to the spelling performance of the students. On the other hand, in addition to the significant contribution of rapid naming to reading performance, phonological strategies were also utilized by the second graders in reading. Thus, this may be due to the fact that after reaching 
an advanced level in spelling ability, in addition to automatization skills, phonological knowledge was also started to be used in reading ability, which is in accord with the stage model by Frith (1985).

In conclusion, the present study examined the roles of phonological awareness and RAN in reading and spelling performances of students in Grade 1 and 2 as little research has focused on phonological awareness and RAN especially in spelling performances of Turkish speaking children (e.g., Babayiğit \& Stainthorp, 2010; Sönmez, 2015). In this sense, the results of the current study can provide more insight into Turkish literacy development. Moreover, the results from the present study contribute new information about the stage model by Frith (1985), which explains the relationship between reading and spelling skills in an opaque language, English. The findings demonstrate that the stage model by Frith (1985) is also applicable to a transparent language, Turkish.

\subsection{Limitations and implications}

There are some limitations of the study that need to be borne in mind. First, the findings of the study may not be generalized to larger populations as convenience sampling was used as a method of data collection to reach the participants. Using a wider sample of participants chosen by random sampling would be better in terms of generalizability of the study. Moreover, the findings may be generalized only to orthographies with similar characteristics to Turkish.

In addition, due to the time limitations, data in the current study were collected from the participants at a single point in time, making use of cross-sectional research design. A longitudinal study in which the same participants are followed to later grades would be useful in order to examine the relationship of phonological encoding and rapid naming to Turkish spelling and reading development. Furthermore, the participants were not tested in terms of their verbal ability and memory, which would enhance our understanding about reading and spelling development in early years.

Lastly, data in the current study were collected from children in Grade 1 and 2 and children in kindergarten were not included in the study. This is because in Turkey, children do not start learning how to read and write in the kindergartens. Also, the activities for developing phoneme-grapheme awareness of students are mostly limited to vowels in the kindergartens.

Despite these limitations, the findings of the present study have important implications for instructional practice. As the results of the current study suggest, at the beginning of the literacy development, spelling and reading skills utilize different strategies and knowledge. While students make use of their phonological knowledge in spelling, they apply orthographic knowledge in reading. Thus, educators should be aware of this fact and arrange the curriculum accordingly. In other words, spelling should be taught as a separate skill by keeping in mind that during spelling different strategies are activated than the ones in reading. Also, activities enhancing phonological and orthographic knowledge can be included in the curriculum in order to reinforce the development of reading and spelling. However, at later stages, when these two skills become linked, the growth in one ability will have an impact on the other, according to Frith's stage model (1985). Thus, teachers should be aware of this relationship between reading and spelling. In practice, they might arrange activities promoting this relationship.

In conclusion, the findings of this research are important. In practical terms, these results have the potential to support teachers' classroom practices in designing reading and spelling tasks. Moreover, they may contribute to the development of the curriculum and teaching materials as well as the production of new assessment tools in primary schools. 


\section{Ethics Committee Approval}

The authors confirm that the study does not need ethics committee approval (Date of Confirmation: 02.02.2020)

\section{References}

Aarnoutse, C., van Leeuwe, J., \& Verhoeven, L. (2005). Early literacy from a longitudinal perspective. Educational Review and Research, 11, 253-275.

Aidinis, A., \& Nunes, T. (2001). The role of different levels of phonological awareness in the development of reading and spelling in Greek. Reading and Writing: An Interdisciplinary Journal, 14(1-2), 145-177.

Babayigit, S., \& Stainthorp, R. (2007). Preliterate phonological awareness and early literacy skills in Turkish. Journal of Research in Reading, 30(4), 394-413.

Babayigit, S., \& Stainthorp, R. (2010). Component processes of early reading, spelling, and narrative writing skills in Turkish: A longitudinal study. Reading and Writing: An Interdisciplinary Journal, 23(5), 539-568.

Babayiğit, S., \& Stainthorp, R. (2011). Modeling the relationships between cognitive-linguistic skills and literacy skills: New insights from a transparent orthography. Journal of Educational Psychology, 103(1), 169-189.

Badian, N. A. (1993). Phonemic awareness, naming, visual symbol processing, and reading. Reading and Writing: An Interdisciplinary Journal, 5(1), 87-100.

Bakır, H., \& Babür, N. (1-3 Ekim, 2009). Türkçe hızlı otomatik isimlendirme (HOTI) testleri'nin gelişstirilmesi ve ön bulgular. Bildiri, 18. Ulusal Eğitim Bilimleri Konferansı. Selçuk, Izmir.

Bakır, H., \& Babür, N. (2018). Hızlı otomatik isimlendirme testinin Türkçeye uyarlanması. Boğaziçi Üniversitesi Ĕ̈itim Dergisi, 35(2), 67-83.

Bowers, P. G., \& Swanson, L. B. (1991). Naming speed deficits in reading disability: Multiple measures of a singular process. Journal of Experimental Child Psychology, 51(2), 195-219.

Bowers, P. G., \& Wolf, M. (1993). Theoretical links between naming speed, precise timing mechanisms and orthographic skill in dyslexia. Reading and Writing: An Interdisciplinary Journal, $5(1), 69-85$.

Bradley, L., \& Bryant, P. E. (1983). Categorizing sounds and learning to read: A causal connection. Nature, 301, 419-421.

Bryant, P. E., \& Bradley, L. (1980). Why children sometimes write words which they do not read. In U. Frith (Ed.), Cognitive processes in spelling (pp. 355-370). Orlando, FL: Academic Press.

Candan, E., Babür, N., Haznedar, B., \& Erçetin, G. (2020). Reading and spelling skills in transparent orthographies: Phonological encoding and rapid automatized naming in Turkish. In Alves, R.A., Limpo, T. \& Joshi, R. M. (Eds.). Reading-writing connections: Towards integrative literacy science (pp. 185-201). Switzerland AG: Springer. 
Caravolas, M., Hulme, C., \& Snowling, M. (2001). The foundations of spelling ability: Evidence from a 3-year longitudinal study. Journal of Memory and Language, 45(4), 751-774.

Caravolas, M., Volín, J., \& Hulme, C. (2005). Phoneme awareness is a key component of alphabetic literacy skills in consistent and inconsistent orthographies: Evidence from Czech and English children. Journal of Experimental Child Psychology, 92(2), 107-139.

Caravolas, M., \& Samara, A. (2015). Learning to read and spell words in different writing systems. In A. Pollatsek \& R. Treiman (Eds.), The Oxford handbook of reading (pp. 326-343). New York, NY, Oxford University Press.

Cornwall, A. (1992). The relationship of phonological awareness, rapid naming, and verbal memory to severe reading and spelling disability. Journal of Learning Disabilities, 25(8), 532-538.

de Jong, P.F., \& van der Leij, A. (2002). Effects of phonological abilities and linguistic comprehension on the development of reading. Scientific Studies of Reading, 6(1), 51-77.

Denckla, M. B., \& Rudel, R. G. (1974). Rapid automatized naming of pictured objects, colors, letters and numbers by normal children. Cortex, 10(2), 186-202.

Denckla, M. B., \& Rudel, R. G. (1976a). Naming of objects by dyslexic and other learning disabled children. Brain and Language, 3(1), 1-15.

Denckla, M. B., \& Rudel, R. G. (1976b). Rapid automatized naming (R.A.N): Dyslexia differentiated from other learning disabilities. Neuropsychologia, 14(4), 471-479.

Eme, E., \& Golder, C. (2005). Word-reading and word-spelling styles of French beginners: Do all children learn to read and spell in the same way? Reading and Writing: An Interdisciplinary Journal, 18(2), 157-188.

Fletcher-Flinn, C. M. , Shankweiler, D., \& Frost, S. J. (2004). Coordination of reading and spelling in early literacy development: An examination of the discrepancy hypothesis. Reading and Writing: An Interdisciplinary Journal, 17, 617-644.

Frith, U. (1980). Unexpected spelling problems. In U. Frith (Ed.), Cognitive processes in spelling (pp. 495-515). London: Academic Press.

Frith, U. (1985). Beneath the surface of developmental dyslexia. In K. E. Patterson, J. C. Marshall \& M. Coltheart (Eds.), Surface dyslexia (pp. 301-330). Hillsdale, NJ: Lawrence Erlbaum Associates.

Furnes, B., \& Samuelsson, S. (2010). Predicting reading and spelling difficulties in transparent and opaque orthographies: A comparison between Scandinavian and U.S./Australian children. Dyslexia, 16(2), 119-142.

Furnes, B., \& Samuelsson, S. (2011). Phonological awareness and rapid automatized naming predicting early development in reading and spelling: Results from a cross linguistic longitudinal study. Learning and Individual Differences, 21(1), 85-96.

Gentry, J. R. (1982). An analysis of developmental spelling in "GNYS AT WORK". The Reading Teacher, 36, 192-200. 
Georgiou, G., Torppa, M., Manolitsis, G., Lyytinen, H., \& Parrila, R. (2012). Longitudinal predictors of reading and spelling across languages varying in orthographic consistency. Reading and Writing: An Interdisciplinary Journal, 25(2), 321-346.

Gillon, G. T. (2007). Phonological awareness: From research to practice. New York: Guilford.

Goswami, U., \& Bryant, P. (1990). Phonological skills and learning to read. East Sussex: Erlbaum.

Goswami, U., Ziegler, J., \& Richardson, U. (2006). The effects of spelling consistency on phonological awareness: A comparison of English and German. Journal of Experimental Child Psychology, 92(4), 345-365.

Joshi, R. M. \& Aaron, P. G. (2006). Handbook of orthography and literacy. Mahwah, NJ: Erlbaum.

Kirby, J. R., Parrila, R., \& Pfeiffer, S. (2003). Naming speed and phonological awareness as predictors of reading development. Journal of Educational Psychology, 95(3), 453-464.

Landerl, K., \& Wimmer, H. (2008) Development of word reading fluency and spelling in a consistent orthography: An 8-year follow-up. Journal of Educational Psychology, 100(1), 150-161.

Lehtonen, A. (2006). The sources of information children use in learning to spell: The case of Finnish geminates. In R. M. Joshi \& P. G. Aaron (Eds.), Handbook of orthography and literacy (pp. 6379). Mahwah, NJ: Erlbaum.

Muter, V., Hulme, C., Snowling, M., \& Stevenson, J. (2004). Phonemes, rimes, vocabulary, and grammatical skills as foundations of early reading development: Evidence from a longitudinal study. Developmental Psychology, 40(5), 665-681.

Nikolopoulos, D., Goulandris, N., Hulme, C., \& Snowling, M. J. (2006). The cognitive bases of learning to read and spell in Greek: evidence from a longitudinal study. Journal of Experimental Child Psychology, 94(1), 1-17.

Norton, E. S., \& Wolf, M. (2012). Rapid automatized naming (RAN) and reading fluency: Implications for understanding and treatment of reading disabilities. Annual Review of Psychology, $63,427-452$.

Otto, B. (2008). Literacy development in early childhood: reflective teaching for birth to age eight. New Jersey: Pearson Education.

Öney, B., \& Durgunoglu, A. Y. (1997). Learning to read in Turkish: A phonologically transparent orthography. Applied Psycholinguistics, 18(1), 1-15.

Perfetti, C. A. (1997). The psycholinguistics of spelling and reading. In Perfetti, C. A., Rieben, L., \& Fayol, M. (Eds.). Learning to spell: research, theory and practice across languages (pp. 21-38). Mahwah, NJ: Lawrence Erlbaum Associates.

Plaza, M., \& Cohen, H. (2003). The interaction between phonological processing, syntactic awareness, and naming speed in the reading and spelling performance of first-grade children. Brain and Cognition, 53(2), 287-292.

Savage, R., Pillay, V., \& Melidona, S. (2008). Rapid serial naming is a unique predictor of spelling in children. Journal of Learning Disabilities, 41(3), 235-250. 
Seymour, P. H. K., Aro, M., \& Erskine, J. M. (2003). Foundation literacy acquisition in European orthographies. British Journal of Psychology, 94(2), 143-174.

Sönmez, E. (2015). An investigation of spelling skills in Turkish: The role of phonological encoding and rapid naming in the literacy skills of third and fourth graders. (Unpublished MA Dissertation). Boğaziçi University. Istanbul.

Stainthorp, R., Powell, D., \& Stuart, M. (2014). Deficits in orthographic knowledge in children poor at rapid automatized naming (RAN) tasks? Scientific Studies of Reading, 18(3), 192-207.

Torgesen, J. K., Wagner, R. K., Rashotte, C. A., Burgess, S. R., \& Hecht, S.A. (1997). Contributions of phonological awareness and rapid autonomic naming ability to the growth of word-reading skills in second- to fifth-grade children. Scientific Studies of Reading, 1, 161-185.

Verhagen, W., Aarnoutse, C., \& Leeuwe, J. (2010). Spelling and word recognition in Grades 1 and 2: Relations to phonological awareness and naming speed in Dutch children. Applied Psycholinguistics, 31(1), 59-80.

Wagner, R., Torgesen, J., Rashotte, C., Hecht, S., Barker, T., Burgess, S., Donahue, J. \& Garon, T. (1997). Changing relations between phonological processing abilities and word-level reading as children develop from beginning to skilled readers: A 5-year longitudinal study. Developmental Psychology, 33(3), 468-79.

Wimmer, H. Landerl, K. Frith, U. (1999). Learning to read German: Normal and impaired acquisition. In M. Harris \& G. Hatano (Eds.), Learning to read and write: A cross-linguistic perspective. (pp. 34-50). Cambridge: Cambridge University Press.

Wimmer, H., \& Mayringer, H. (2002). Dysfluent reading in the absence of spelling difficulties: A specific disability in regular orthographies. Journal of Educational Psychology, 94(2), 272-277.

Wimmer, H., Mayringer, H., \& Landerl, K. (2000). The double-deficit hypothesis and difficulties in learning to read a regular orthography. Journal of Educational Psychology, 92(4), 668-680.

Wolf, M., \& Bowers, P. (1999). The double-deficit hypothesis for the developmental dyslexias. Journal of Educational Psychology, 91(1), 1-24. 


\section{Fonolojik bilgi ve hılı isimlendirmenin Türkçe okuma-yazma ve imla gelişimindeki rolü}

\section{$\ddot{O} z$}

Bu çalışma, ilkokul 1. ve 2. sınıf öğrencilerinin Türkçe okuma, yazma ve imla gelişimini incelemektedir. Çalışma kapsamında, kelime düzeyinde okuma ve yazma becerileri yordayıcılarının yanı sıra, bu beceriler arasındaki gelişimsel ilişki de incelenmiştir. Özellikle fonolojik kodlama (FK) ve hızlı otomatik isimlendirme (HOTI) becerilerine odaklanılmıştır. Çalışmada, 1. ve 2. sınıfa devam eden toplam 71 öğrenci yer almış ve veriler nicel olarak değerlendirilmiştir. Çalışmanın sonuçları, fonolojik kodlamanın Türkçe yazma becerilerinin önemli bir yordayıcısı olduğunu, hızlı otomatik isimlendirmenin ise, Türkçe' de okumanın yordayıcısı olduğunu göstermektedir. Ayrıca, FK, ikinci sınıf öğrencilerinin okuma becerilerine önemli ölçüde katkıda bulunurken, birinci sınıf öğrencilerinin kelime okuma becerilerine anlamlı bir katkıda bulunmamıştır.

Anahtar sözcükler: Okuma; yazma ve imla; fonolojik kodlama

\section{AUTHOR BIODATA}

Yeliz Yılmaz Korkmaz is an English lecturer in the School of Foreign Languages at Istanbul Yildiz Technical University, Istanbul, Turkey. She completed her master's thesis titled "Spelling Development in Turkish: Phonological Encoding and Rapid Naming Skills in First and Second Graders" in 2019 at Boğaziçi University.

Nalan Babür is an Assistant Professor in the Department of Primary Education at Boğaziçi University, Istanbul, Turkey.

Belma Haznedar is a Professor in the Department of Foreign Language Education at Boğaziçi University, Istanbul, Turkey. 